\title{
Anphira branchialis GEN. ET SP. NOV. (CRUSTACEA, ISOPODA, CYMOTHOIDAE) A GILL CAVITY PARASITE OF PIRANHAS (Serrasalmus SPP.) IN THE BRAZILIAN AMAZON
}

\author{
Vernon E. THATCHER (1)
}

\begin{abstract}
Anphira branchialis gen. et sp. nov. (Crustacea, Isopoda, Cymothoidae) is described from the dorsal areas of the gill chambers of three species of piranhas (Serrasalmus spp.). The fishes were caught in rivers near Manaus, Amazonas State and on Maracá island, Federal Territory of Roraima, Brasil. The new genus and species is characterized by having large, flat coxal plates on all 7 pereonites. These plates usually extend beyond the margins of the following segments and the 7 th ones extend nearly to the pleotelson and cover the lateral margins of the pleonites. The mandible of this species is rounded, "foot shaped" and without incisor. The mandibular palp is short and stout. The maxillules have 3 terminal and 2 subterminal spines. The pleopods are simple lamellar structures with rounded tips. Evidence is presented that these parasites feed on gill filaments.
\end{abstract}

Key words: Isopod, Cymothoid, Parasite, Piranha, Amazon.

Anphira branchialis gen. et sp. nov. (Crustacea, Isopoda, Cymothoidae) Um Parasita da Cavidade Branquial de Piranhas (Serrasalmus spp.) na Amazônia Brasileira.

RESUMO - Anphira branchialis gen. et sp. nov. (Crustacea, Isopoda, Cymothoidae) aqui descrito é proveniente das áreas dorsais das cavidades branquiais de três espécies de piranhas (Serrasalmus spp.). Os peixes foram capturados em rios nas cercanias de Manaus, Estado do Amazonas e na Ilha de Maracá, no Território Federal de Roraima, Brasil. O novo gênero e espécie caracterizam-se por ter placas coxais grandes e achatadas em todos os 7 pereonitos. Cada uma das placas geralmente ultrapassa a margem do segmento seguinte e as sétimas estendem-se quase até o pleotelso, cobrindo as margens laterais dos pleonitos. A mandibula desta espécie é arredondada, em "forma de pé" e carece de incisor. O palpo mandibular é curto e forte. As maxillulas têm três espinhos terminais e dois subterminais. É apresentada evidência sugerindo que estes parasitos comem filamentos branquiais de seus hospedeiros.

Palavras-chave: Isopode, Cymothoidae, Parasita, Piranha, Amazônia

\section{INTRODUCTION}

Species of the fish genus Serrasalmus, commonly called piranhas, are widely known for their voracity. They feed on other fishes, crustaceans, insects and other living prey. Our studies show that at least four genera of cymothoid isopods occur in piranhas. One of these, Asotana magnifica has already been described by THATCHER (1988), An additional species is described in the present work and the other two are under study.

\section{MATERIAL AND METHODS}

The methods used were similar to those explained in THATCHER \& CARVALHO (1988).

1 Instituto Nacional de Pesquisas da Amazônia, Coordenação de Pesquisas em Biologia Aquática, Caixa Postal 478, 69011-970, Manaus, Amazonas, Brasil 


\section{Isopoda}

\section{Cymothoidae}

ANPHIRA gen. nov.

\section{Generic diagnosis}

Female: Body ovoid in dorsal view, about 1.8 times longer than wide; dorsum of pereon highly convex, asymmetrical. Cephalon immersed in pereonite 1, rotated downward, front margin rounded. Pleon not abruptly narrower than pereon, pleonite 1 slightly immersed in pereonite 7 ; all pleonites produced laterally. Mouthparts: mandible rounded, "footshaped", without incisor, palp stout; maxillule with 3 terminal and 2 subterminal recurved spines. Pereonites 2-6 subequal, 1 longer and 7 shorter than others; coxae flattened, plate-like. present on all 7 pereonites, produced posteriorly to or beyond anterior margin of subsequent pereonite. Pereopods short, 2-6 subequal in length, 1 shorter and 7 longer than others. Uropods slender rami pointed, subequal. Pleopods lamellar with rounded extremities. Pleotelson not keeled, rounded posteriorly. Type species: Anphira branchialis sp. nov.

Anphira branchialis sp. nov. (Figs. 1-28)

Hosts: Serrasalmus spilopleura (Kner); S. nattereri (Kner); Serrasalmus sp.

Site: Dorsal part of gill chamber.

Material Examined: 1 male \& 1 female from $S$. nattereri; 17 April 87; Lago Calado (near Manaus); col. P. Petri. 1 male \& 1 female from $S$. spilopleura; 25 Feb. 86; Lago do Rei (near Manaus); col. E. Ferreira. I male from Serrasalmus sp.; no date; Ilha de Maracá, Roraima; col. M. Jégu. 4 males from $S$. na

$S$. nattereri; no date; vicinity of Manaus, 1 female (no date) from $S$. nattereri, Manaus.

Holotype (female): Crustacean Collection, Instituto Nacional de Pesquisas da Amazônia (INPA). AM, Brasil. (INPA-CR-643).

Paratypes: 1 female and 7 males at INPA (INPA-CR-644a-h): 1 female and 1 male at the United States National Museum. Smithsonian Institution. Washington, D.C.

Etymology: The generic name is an anagram of the common name of the host fish, "piranha." The species name is in reference to the gill chamber site which this species inhabits.

Species diagnosis: (based on $3 \mathrm{fe}-$ males and 4 males; measurements in Table 1). Female (Figs. 1-3;8): body about 1.8 times longer than wide. widest at pereonite 4 ; pereon convex. peaked or humpped dorsally; color varies from nearly white to dark brown. melanophores small. Cephalon immersed in pereonite 1 , rotated ventrally. frontal margin rounded, eyes prominent. Antennules and antennae (Figs $15,16)$ subequal in length; antennules slightly compressed, of 8 articles; antennae subcylindrical, of 9 articles.

Mouthparts (Figs. 10-14;17): labrum projecting ventrally, not folding under mandibles; mandible blunt, rounded, "foot-shaped", without incisor; labium with lobes attached to man- 
dibles; maxillule with 3 terminal, and 2 subterminal recurved spines; maxilla bilobed with 1 recurved spine on each lobe; maxillipedal palp with 2 recurved spines, 1 terminal and 1 subterminal (Fig. 13).

Pereonites (Figs. 1;3): first one nearly 2 times as long as $2-6$; 7 th onehalf length of 6 ; coxae (Figs. $3 ; 9$ ) large, flat, plate-like, overlapping, present on all 7 pereonites, produced posteriorly to posterior near margins of following pereonites; 7 th coxae extend to pleotelson covering all pleonites laterally.

Pereopods (Figs. 19-20; 23-26): 2-6 subequal in size, 1 smaller and 7 longer than others; allpereopods terminating in curved, claw-like dactyls; those on $1 \& 7$ smaller than those on 2-6.

Uropods (Fig. 21): long, slender, pointed, not reaching posterior margin of pleotelson. Pleotelson (Fig. 1) broadly rounded posteriorly, not dorsally keeled.

Male (Figs, 4-7): similar to female but smaller and less convex dorsally; uropods shorter and more rounded (Fig. 22). Appendix masculinum present on second pleo-

Table 1. Measurements $(\mathrm{mm})$ of 3 males and 3 females of Anphira branchialis gen. et sp. nov..

\begin{tabular}{lrrrr}
\hline Sex & \multicolumn{2}{c}{ Body } & \multicolumn{2}{c}{ Pleotelson } \\
& \multicolumn{1}{c}{$\mathrm{L}$} & $\mathrm{W}$ & $\mathrm{L}$ & $\mathrm{W}$ \\
\hline Males & 9.4 & 5.0 & 2.5 & 3.0 \\
& 12.5 & 7.0 & 3.5 & 4.3 \\
& 13.9 & 7.7 & 4.0 & 4.5 \\
Females & 12.5 & 6.7 & 4.0 & 4.7 \\
& 18.5 & 10.5 & 4.0 & 6.2 \\
& 21.0 & 11.6 & 6.5 & 7.5 \\
\hline
\end{tabular}

pods of both sexes (Fig. 18b).

Both sexes parasitic in the dorsal regions of the gill chambers of piranhas.

\section{DISCUSSION}

Anphira gen. nov. can be distinguished from the other genera of Cymothoidae by the presence of large, overlapping coxal plates on all 7 pereonites. Normally, coxal plates do not occur on the first pereonite of this family. RICHARDSON (1905) referred to these structures as "epimera" and considered their absence from the first segment to be an important family characteristic. BRUSCA (1981) stated that, "these plates generally remain largely free from their respective pereonal segment, only first being fused." He goes on to say, "in at least some species, (e.g. Indusa carinata Richardson, 1904) fusion of the first dorsal coxal plate with its pereonite is incomplete." According to the description of $I$. carinata in BRUSCA's paper the coxal plates are small and do not reach the posterior margins of their own pereonites.

Mothocya Costa, 1851, and Irona Schioedte \& Meinert, 1884, (considered to be synonyms by MONOD, 1971) are marine genera that inhabit the branchial chambers of their hosts and have plate-like dorsal extensions of the coxae. The species of these genera have only six such plates, however.

This new cymothoid probably feeds on gill filament epithelium and 


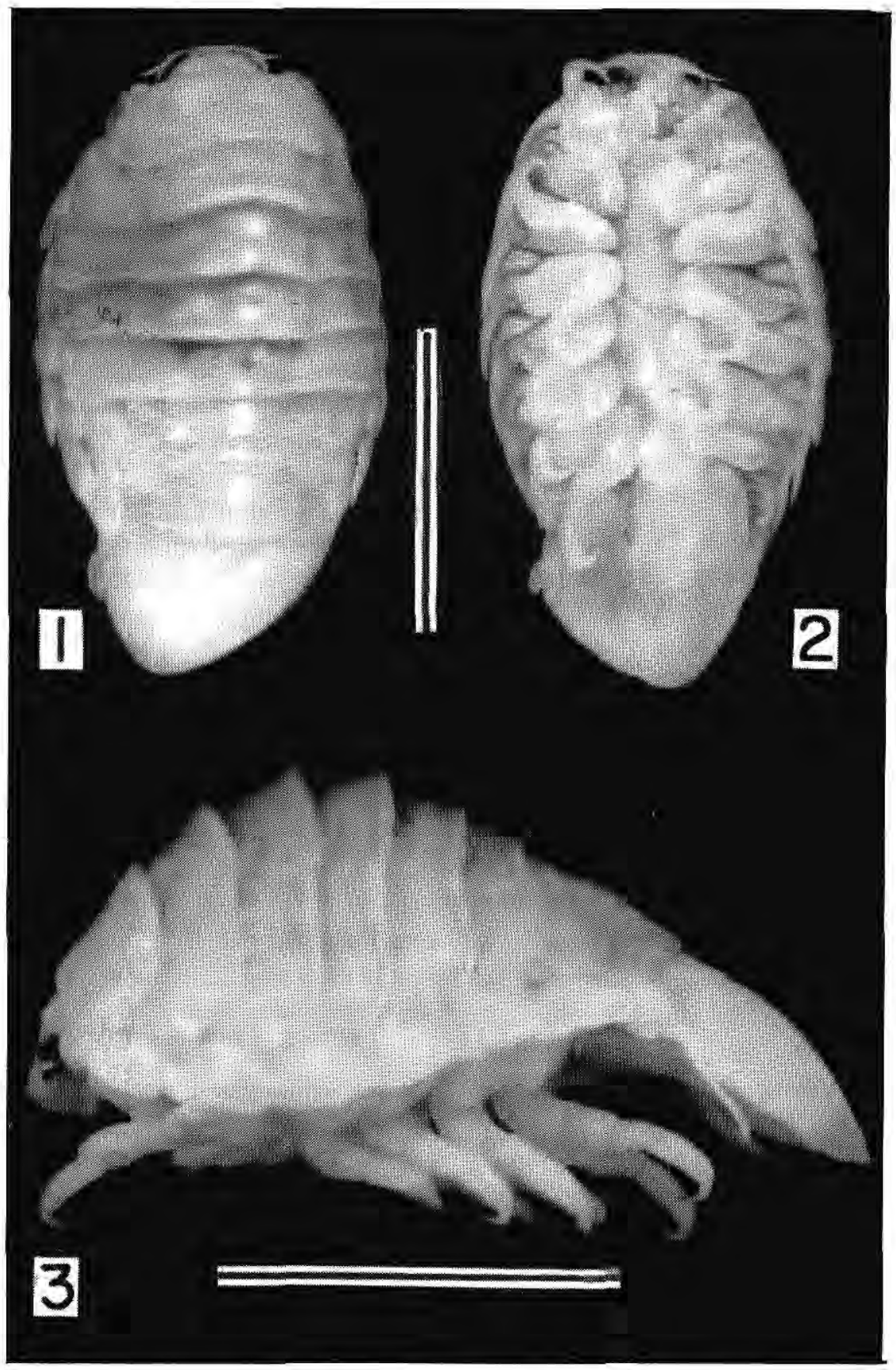

Figuras 1-3. Anphira branchialis gen. et sp. nov. (female). I Dorsal view. 2. Ventral view. 3. Lateral view. Scales $=10 \mathrm{~mm}$. 


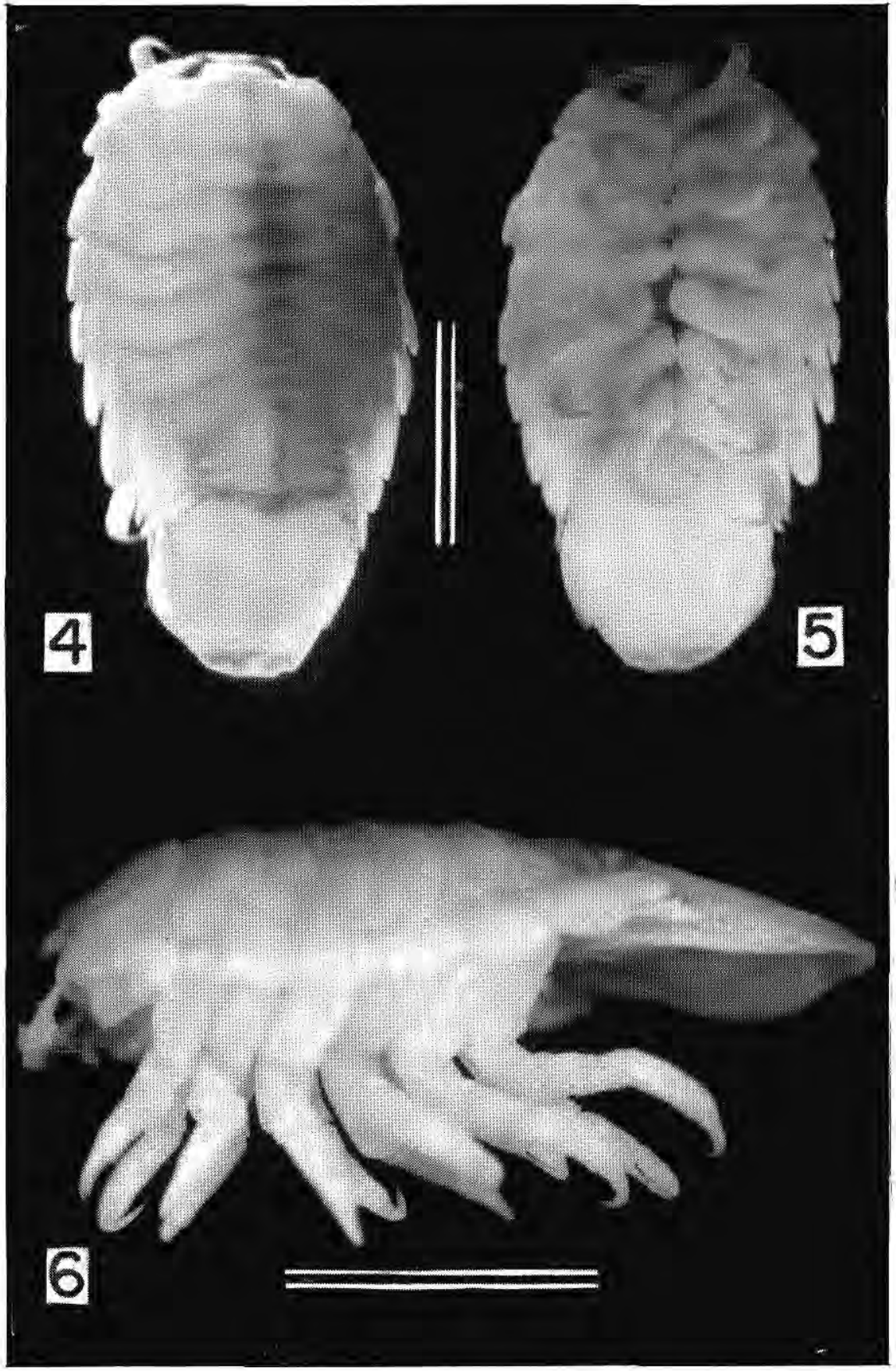

Figuras 4-6. Anphira branchialis gen, et sp, nov. (male). 4. Dorsal view. 5. Ventral view. 6. Lateral view. Scales $=5 \mathrm{~mm}$. 


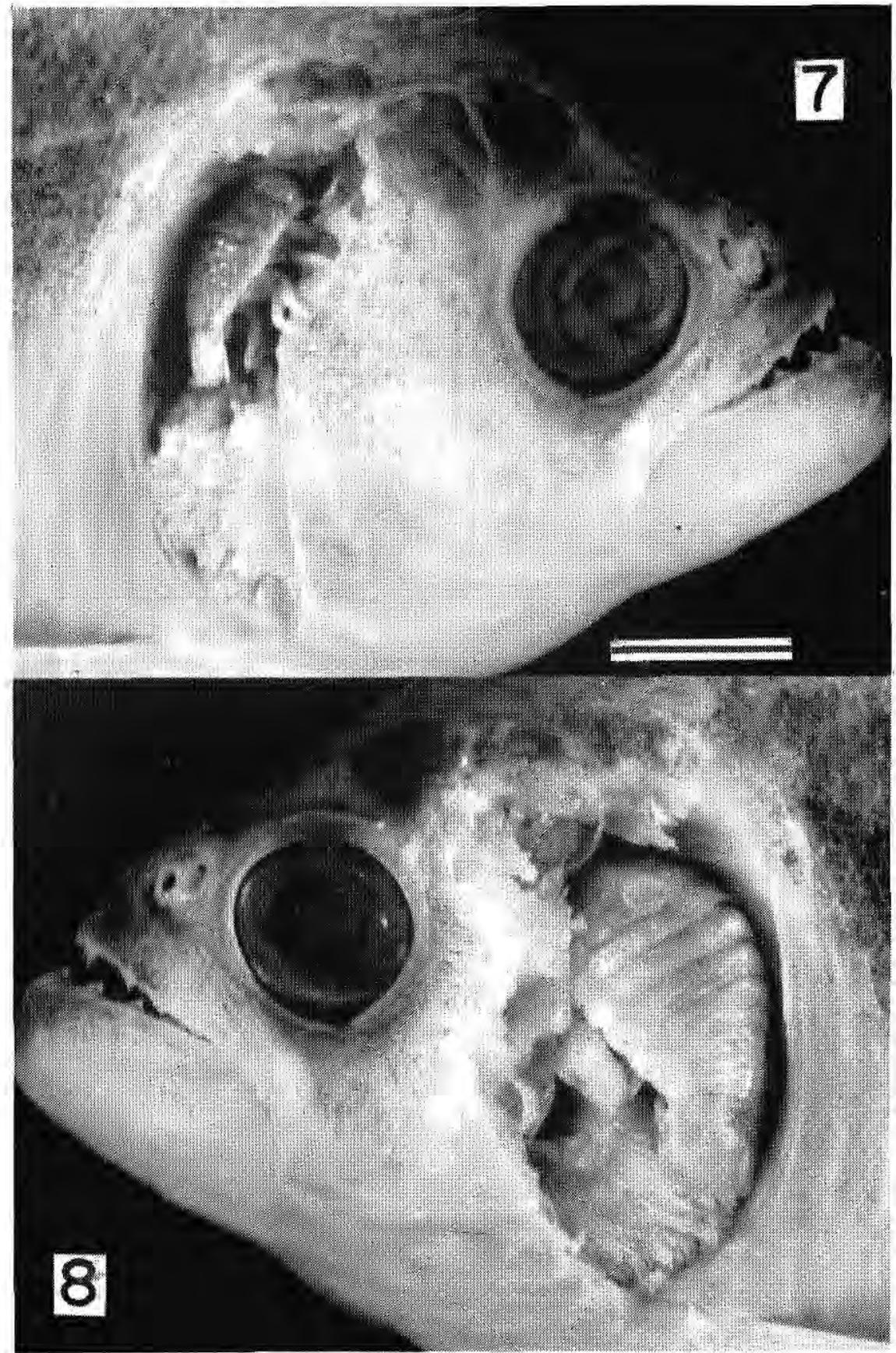

Figuras 7-8. Anphira branchialis gen. et sp. nov, in gill chambers of Serrasalmus sp. 7. Male in right gill cavity. 8 . Female in left gill chamber of same fish (opercula removed). Scale $=10$ $\mathrm{mm}$. 


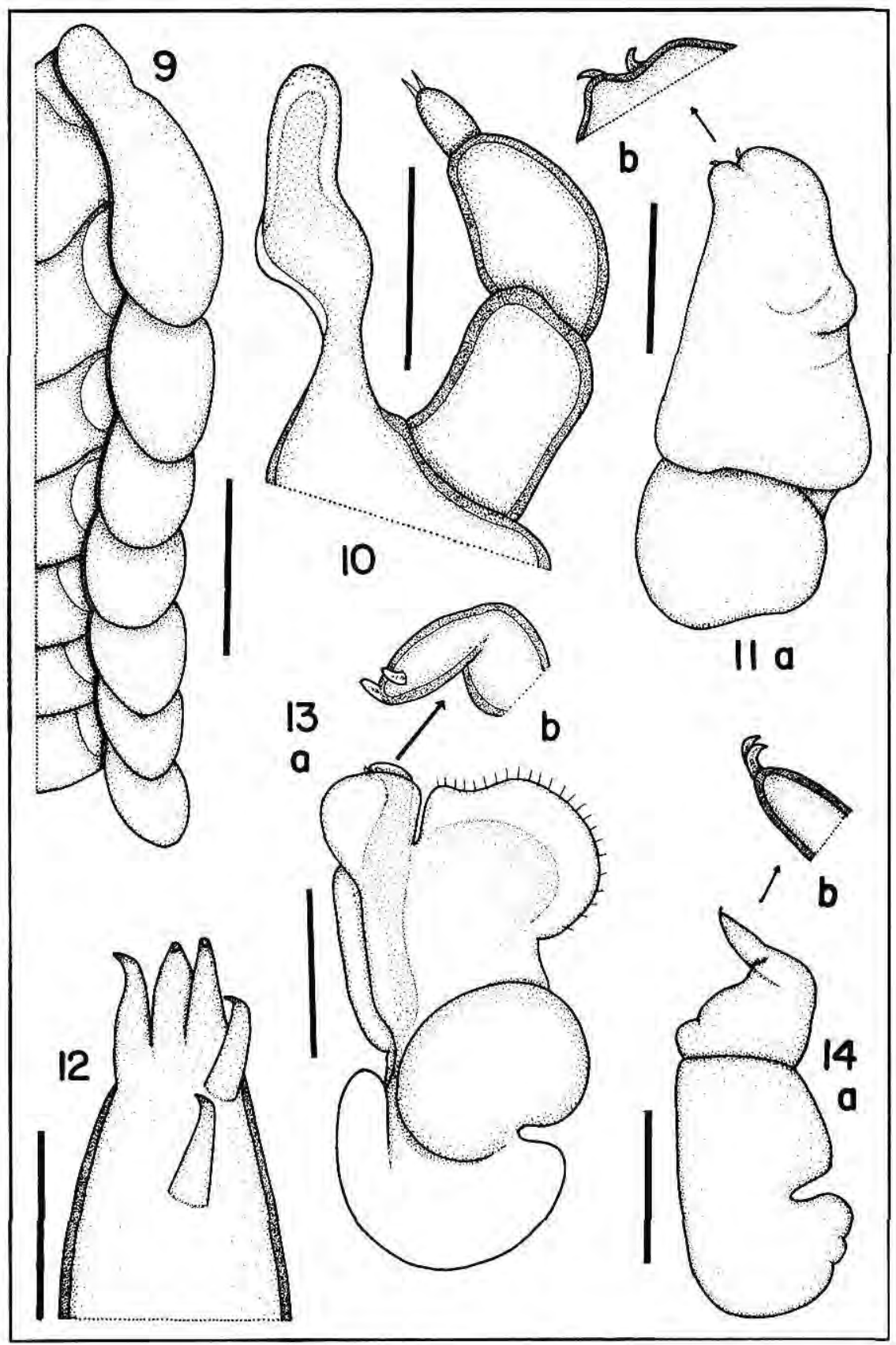

Figuras 9-14. Anphira branchialis gen. et sp. nov. 9. Coxal plates (female; lateral view). 10. mandible and palp (female). 11. Maxilla (female). 12. Maxillule (female). 13. Maxilliped (fernale). 14. Maxilliped (male). Scales: $9=2 \mathrm{~mm} ; 10,11,14=500 \mu: 12=100 \mu: 13=1$ $\mathrm{mm}$. 


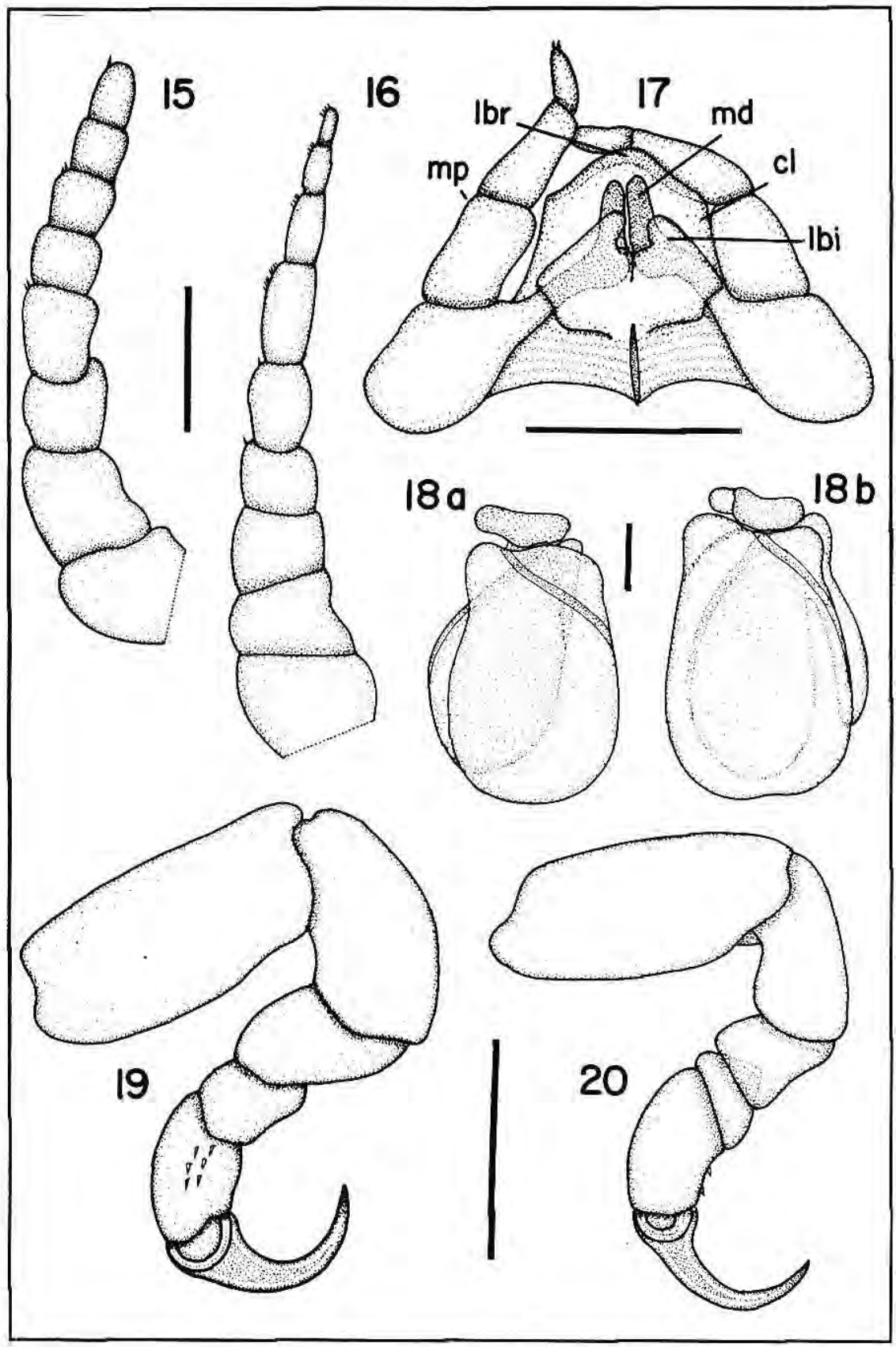

Figuras 15-20. Anphira branchialis gen. et noy. (female). 15. Antennule. 16. Antenna. 17. Mouthparts $(\mathrm{cl}=$ clypeus; $\mathrm{lbi}=$ labium; $\mathrm{lbr}=\mathrm{labrum} ; \mathrm{md}=$ mandible; $\mathrm{mp}=$ mandibular palp). 18a. Pleopod 1. 18b. Pleopod 2. 19. Pereopod 4. 20 Pereopod 1. Scales: $15,16=500 \mu ; 17,18$ $=1 \mathrm{~mm} ; 19,20=2 \mathrm{~mm}$. 


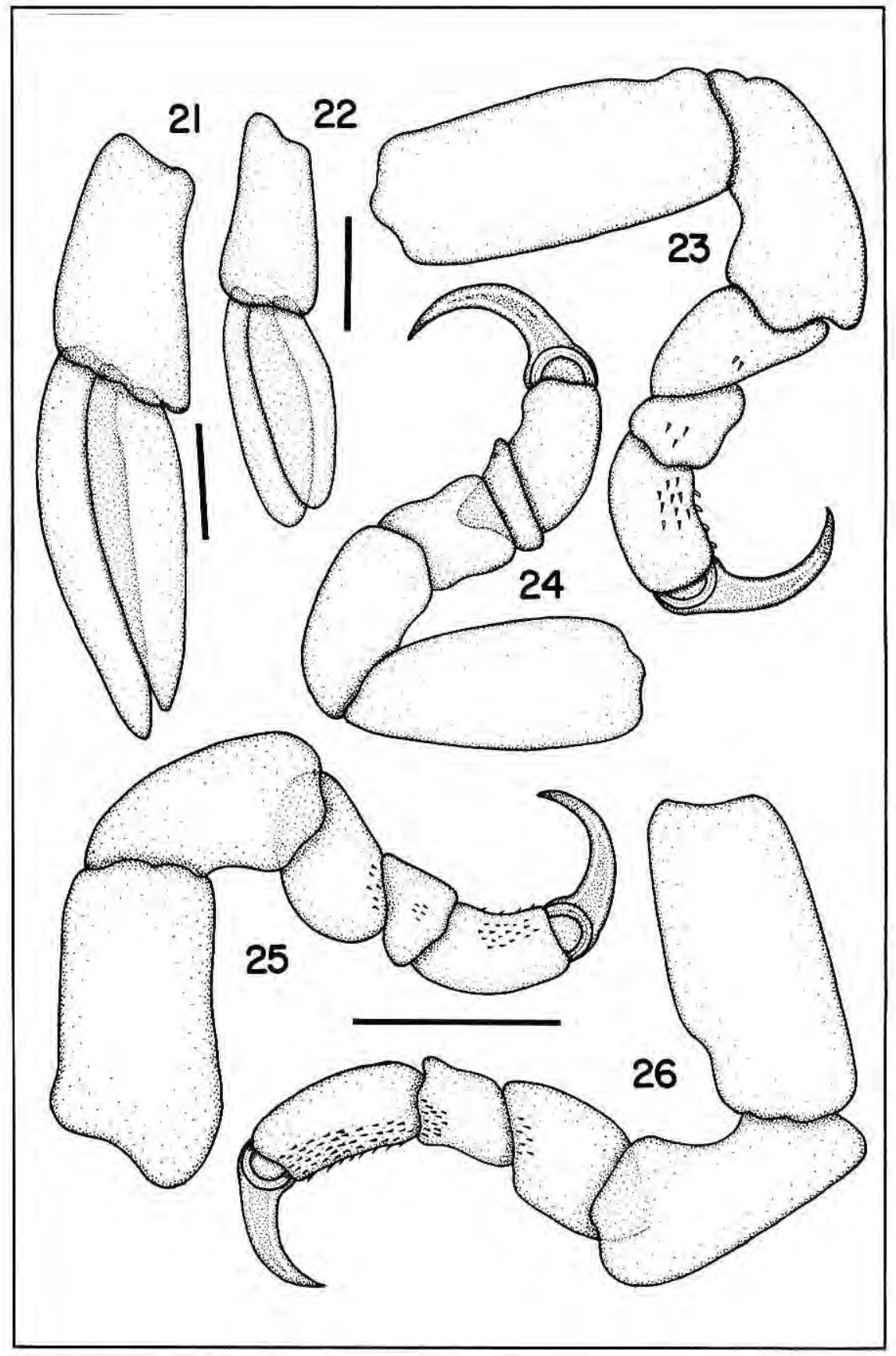

Figuras 21-26. Anphira branchialis gen. et sp. nov. 21. Uropod (female). 22. Uropod (male). 23-26. Pereopods (female): 23. Pereopods 5. 24. Pereopod 2. 25. Pereopod 6. 26. Pereopod 7. Scales: $21,22=500 \mu ; 23-272 \mathrm{~mm}$. 

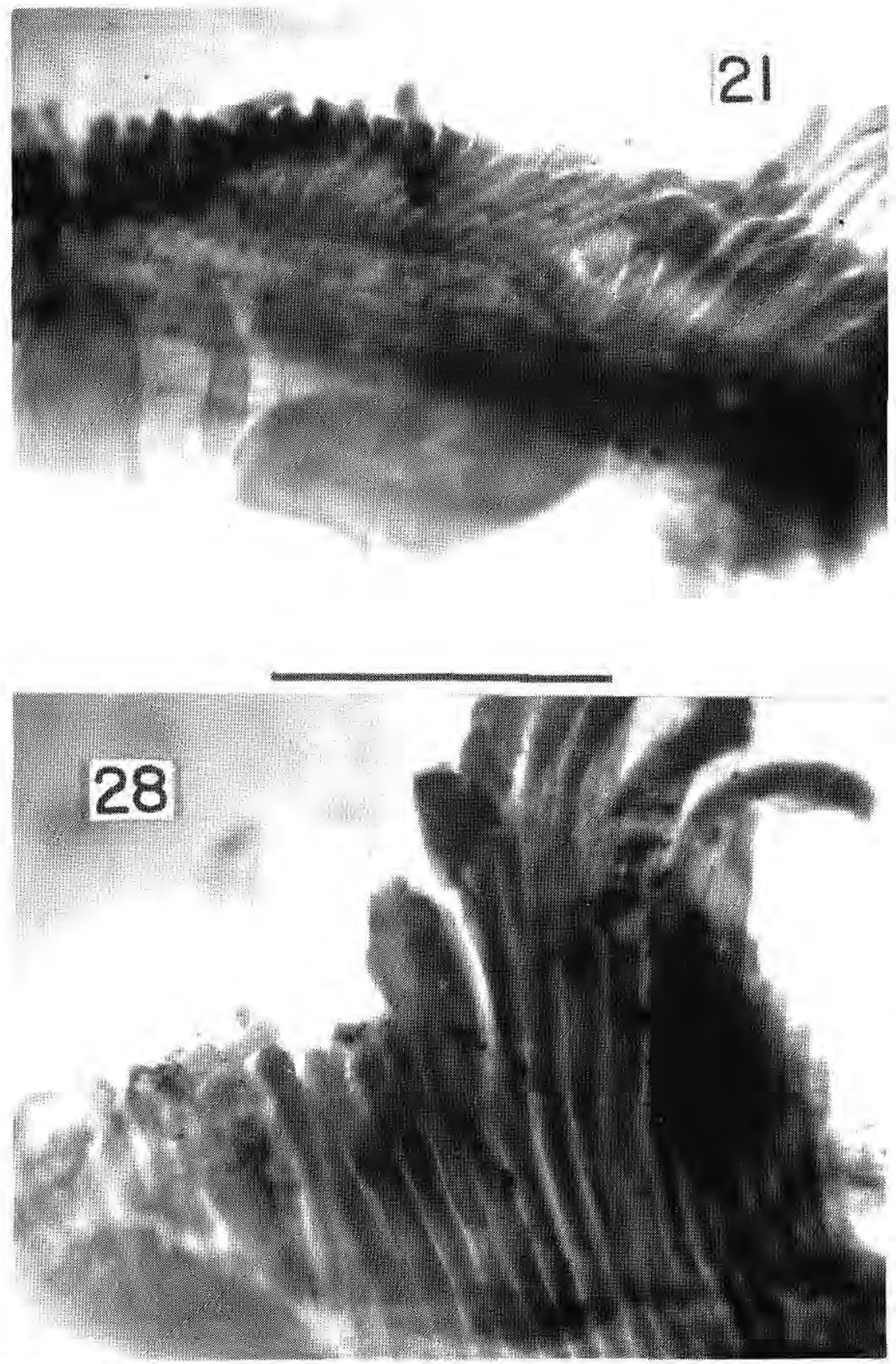

Figuras 27-28. * Gills of Serrasalmus sp. damaged by Anphira branchialis gen. et sp. nov. 27. Shortened filaments and epithelial tumoroids. 28. Abberant and fused filaments. Scale $=$ $2 \mathrm{~mm}$. 
blood cells of its host and therefore should be considered pathogenic. Figs. $7 \& 8$ show that the isopods occupy cavities in the gill chambers that were formerly occupied by gill filaments. Figs. $27 \& 28$ illustrate gill damage caused by this parasite, inluding; tumoroid growths, filament fusion and filament loss. Such extensive loss of gill filaments doubtless affects the respiratory capacity and metabolic efficiency of the host fish.

\section{Literature Cited}

BRUSCA, R. C. 1981. A monograph on the Isopoda, Cymothoidae (Crustacea) of the Eastern Pacific. Zool. Jour. Linnean Soc., 73: 117-199.
RICHARDSON, H. 1905. A monograph on the isopods of North America. Bull. U.S. Nat. Mus., (54). 727 p.

MONOD, T. 1971. Sur quelques crustacés de Tulear. Thethys Suppl. 1: 165-192.

THATCHER, V. E. 1988. Asotana magnifica n. sp. (Isopoda, Cymothoidae) an unusual parasite (commensal?) of the buccal cavity of piranhas (Serrasalmus sp.) from Roraima, Brasil. Amazoniana, 10(3):239-248.

THATCHER, V. E, CARVALHO, M. L. 1988. Artystone minima $\mathrm{n}$. sp. (Isopoda, Cymothoidae) a body cavity parasite of the pencil fish (Nannostomus beckfordi Guenther) from the Brazilian Amazon. Amazoniana, 10(3):255-265. 